\title{
NEM GÊNIO, NEM HERÓI: Nietzsche, Renan e a figura de Jesus
}

\author{
Neither genius nor hero: Nietzsche, \\ Renan and the figure of Jesus
}

\author{
Ernani Chaves, ${ }^{a}$ Allan Davy Santos Sena ${ }^{b}$ \\ a Doutor em Filosofia pela USP. Professor associado I da Faculdade de Filosofia da Universidade \\ Federal do Pará, Belém, PA - Brasil, e-mail: erna.nic@hotmail.com \\ b Licenciado em Ciências da Religião pela Universidade do Estado do Pará. Graduando em \\ Filosofia pela Universidade Federal do Pará. Bolsista PIBIC/Cnpq, desenvolvendo pesquisa \\ sobre a Filosofia da Religião em Nietzsche. Belém, PA - Brasil, e-mail: allandavy@ bol.com.br
}

\section{Resumo}

O objetivo deste artigo é apresentar, nas suas linhas mais gerais, a confrontação de Nietzsche, no Anticristo, com a obra de Ernest Renan, o historiador francês da religião, em especial com A Vida de Jesus. No centro dessa confrontação está a figura de Jesus. Após apresentarmos os aspectos metodológicos envolvidos na questão, o que implica na discussão a respeito do historicismo do século XIX, mostra-se a caracterização feita por Renan da figura de Jesus como "gênio" e "herói”. Ao mesmo tempo, são apontados os elementos da crítica de Nietzsche a essa interpretação, que interessada na questão acerca do "tipo psicológico do Redentor", define-o como sendo a do "idiota", termo de forte ressonância dostoiewskiana.

Palavras-chave: Gênio; Herói; Psicologia; Idiota. 


\begin{abstract}
The main intention of this article is to present, in general terms, the confrontation of Nietzsche's The Anti-Christ with the work of Ernest Renan, french historian of religion, particularly in The Life of Jesus. In the center of such confrontation is the figure of Jesus. After presenting the methodological aspects concerning the question, which means a discussion about the historicism of the XIX Century, we show the characterization made by Renan of the figure of Jesus as "genius" and "hero". At the same time, we expose the elements of Nietzsche's critique of that interpretation, which, interested in the matter of the "redemptor's psychological type", defines it as "idiot", a term with strong dostoyerskian resonance.
\end{abstract}

Keywords: Genius; Hero; Psychology; Idiot.

\title{
À memória de Fabiano Ribeiro de Sena
}

\section{I}

A importância do historiador francês Ernest Renan para as discussões e análises de Nietzsche acerca do cristianismo é sobejamente conhecida. Cumpre observar, de imediato, que a obra de Renan era conhecida de Nietzsche pelo menos desde a época do "idílio de Tribschen", ou seja, desde sua íntima convivência com Richard e Cosima Wagner. Em carta a Wagner, de 18 de abril de 1873, em plena redação da Extemporânea contra David Strauss, Nietzsche menciona a devolução a Cosima, do exemplar do livro de Renan sobre o Apóstolo Paulo, que havia sido emprestado a ele (KSB 4, p. 145). O diário de Cosima, por sua vez, testemunha o interesse sempre presente de Wagner pela obra de Renan. Uma anotação de 04 de dezembro de 1878, ou seja, depois da ruptura com Nietzsche, Wagner, que desprezava os franceses e considerava Paris "o grande bazar do mundo", não deixava de afirmar, numa provável referência à Vida de Jesus, que Renan 
"tinha escrito o melhor livro sobre coisas que nos interessam" (CAMPIONI, 2001, p. 52-53). De fato, Renan representou para Wagner uma decisiva mudança na sua relação com o cristianismo. Lembremos que ele começa como fervoroso leitor de Feuerbach e aceitando, sem reservas, as críticas deste ao cristianismo e às religiões em geral, como engano e ilusão, análise que sabemos, desaguarão, no círculo dos chamados "hegelianos de esquerda", na crítica marxiana da religião como ideologia e alienação. Ora, como o próprio Nietzsche não deixa de nos lembrar no Caso Wagner, a história da vida e da obra de Wagner é marcada pelo abandono dessa posição inicial, "revolucionária", em nome do pessimismo schopenhaueriano: passagem do Siegfried ao Anel (CW 4). Não é por acaso, portanto, que Wagner, assim como Nietzsche, vai também atacar A Vida de Jesus, de David Strauss, embora por razões bem diferentes. Para Wagner, a Vida de Jesus, de Renan, era superior a de Strauss. Na reconstituição proposta por Renan, ele se encanta e se identifica com a apresentação de Jesus como "gênio", que alimentará, mais tarde, as suas análises acerca do conflito razão versus religião e mito. Em 17 de abril de 1878, Cosima anota em seu diário a seguinte observação de Wagner: "Renan ama Jesus, o que não é o caso de Strauss" (CAMPIONI, 2001, p. 52-53). Ora, neste mesmo momento, já afastado de Wagner, Nietzsche encomenda ao seu editor Ernst Schmeitzner, em carta de 23 de abril de 1878, um exemplar da edição alemã dos Diálogos filosóficos, de Renan (KSB 5, p. 324). Embora Wagner vá também romper com sua fascinação por Renan, é inegável que a concepção de Jesus como herói e gênio, advinda do historiador francês, contribuiu bastante para a própria caracterização "heroica" de Parsifal.

A retomada, mesmo que rápida, de alguns aspectos da relação entre Wagner, Nietzsche e a obra de Renan é importante porque ela repercutirá, sobremaneira, nos últimos anos da produção intelectual de Nietzsche, quando sua crítica do cristianismo será inseparável de sua crítica a Wagner. E neste diapasão, se faz necessário, para Nietzsche, intensificar a discussão com Renan e sua concepção de Jesus como gênio e herói. Assim, Nietzsche não apenas assinalava que sua questão, ao contrário da crescente bibliografia acerca da vida de Jesus, se dirigia ao "tipo psicológico do Redentor" e não à investigação acerca de sua figura "histórica", do "homem" Jesus, como também que sua crítica à cristianização de Wagner derivava, em muitos aspectos, de sua crítica a Renan. 
Embora presente, de forma esparsa, em alguns outros momentos da obra de Nietzsche, a crítica a Renan se qualifica e se acentua nos últimos textos, ${ }^{1} \mathrm{em}$ especial no Anticristo. Pode-se dizer, grosso modo, que a tarefa que Nietzsche se propõe nessa obra é a de desvendar a figura de Jesus de Nazaré por meio de uma classificação do seu tipo psicológico. Entretanto, esta pretensão esbarra em uma série de problemas metodológicos. O mais premente consiste em apontar o equívoco em associar o homem Jesus àquela imagem forjada pela tradição cristã ao longo da história. Sem a crítica dessa posição, é impossível compreender o terreno no qual o cristianismo brotou e qual a sua real e funesta natureza. Como nos alerta Nietzsche: “- Já a palavra 'cristianismo' é um mal entendido - no fundo, houve apenas um cristão, e ele morreu na cruz. O 'evangelho' morreu na cruz” (AC 39). Ou seja, o que Jesus realmente foi, a maneira como ele viveu e agiu, constituiria, na acepção mais precisa possível, o único e verdadeiro sentido da palavra "cristão". Após a morte de Jesus, porém, o que passou a ser conhecido como "cristão" e "cristianismo", nada mais é que uma falsificação, uma deformação daquilo que Jesus representou de fato. A questão mais grave é que a imagem deturpada de Jesus é não somente falsa como também representa exatamente o avesso do que Jesus foi e do que ele ensinou. Segundo Nietzsche, "[...] construiu-se a Igreja com base no oposto do evangelho" (AC 36). Sendo assim, como é possível encontrar a autêntica figura de Jesus em meio à tão intransponíveis obstáculos? Com certeza, não com a ajuda dos recursos metodológicos de que a história colocava à disposição naquela época. Para Nietzsche, a história encontra-se, nesse caso, impedida de analisar objetivamente os fatos, visto que os documentos que testemunham os eventos do nascimento do cristianismo são a prova mais cabal da adulteração operada em torno da figura de Jesus. Assim sendo, é impossível analisá-los com os instrumentos científicos usuais de que a história costumava lançar mão. Esta atitude de Nietzsche está em absoluta consonância com sua crítica do Historicismo, ou seja, da concepção de história compreendida como ciência dos fatos do passado, empreendida desde a Segunda consideração extemporânea. Desse modo, Nietzsche não podia concordar com os esforços dos historiadores que visavam reconstruir historicamente a vida de Jesus. Assim, poderíamos dizer que no ponto de partida das reflexões de Nietzsche está uma questão de método. Não se trata, como veremos, de uma questão de menor importância.

1 ABM 48, que contém uma longa citação em francês, retirada do artigo de Renan intitulado ' $L$ ' avenir religieux dês sociétés modernes", que Nietzsche conhecia por meio da leitura dos Essais de psichologie contemporaine, de Paul Bourget; CI Incursões de um Extemporâneo 2, intitulado "Renan" e o 44, acerca do conceito de gênio. Para uma avaliação global dessas citações, CAMPIONI, 2001. 
É neste diapasão, onde questões metodológicas assumem um papel decisivo, que Nietzsche volta a criticar David Strauss no Anticristo. Não enxergar os Evangelhos como o maior indício da deturpação feita em torno da vida e dos ensinamentos de Jesus, utilizando os procedimentos metodológicos usuais da história para analisá-los, foi, de acordo com Nietzsche, o maior erro de David Strauss. Sabe-se que Strauss já havia sido severamente atacado por Nietzsche na primeira das Considerações extemporâneas, por sua obra $A$ velha e a nova $f e ́$, bastante festejada na época pelos círculos eruditos alemães. Em O Anticristo, o filisteu da cultura Strauss, como sentencia Nietzsche na Primeira Extemporânea, é acusado de ter lido os Evangelhos com os olhos do mais ingênuo dos críticos, atacando o que em tais textos é o menor e mais evidente dos problemas, ou seja, suas inúmeras contradições, tão somente para exercitar o "rigor" e a "precisão" dos métodos científicos (AC 28).

Na introdução da sua Vida de Jesus, Ernest Renan também se refere a Strauss de maneira desfavorável. Para Renan, apesar de Strauss ter feito importantes e inegáveis avanços na crítica dos textos evangélicos, o historiador alemão não pôde se desvencilhar do seu ranço teológico, ficando preso a uma análise excessivamente pietista, da qual Renan buscará, a todo custo, se libertar. Portanto, Renan informa, desde a "Introdução" do seu livro, que sua Vida de Jesus é uma réplica aos equívocos cometidos na Vida de Jesus de Strauss, daí a sutil provocação por parte do historiador francês com o uso do mesmo título do livro de Strauss em seu próprio.

Tanto Nietzsche quanto Renan, portanto, discordam, por razões diferentes, dos procedimentos metodológicos utilizados por Strauss. No que se refere à análise dos Evangelhos, Nietzsche afasta qualquer possibilidade de se aplicar os instrumentos científicos de que a história dispõe com vistas a esse objetivo, porquanto a linguagem dos textos evangélicos não pode ser corretamente interpretada pelo raciocínio lógico, pois aqui se trata de "lendas de santos", que não se ajustam a um recorte científico qualquer. Ademais, os Evangelhos só podem ser utilizados como documentos comprobatórios naquilo que se refere à desmedida falsificação da verdadeira história do cristianismo no interior da comunidade cristã inicial responsável pela sua redação. Como alerta Nietzsche: “- Os evangelhos são inestimáveis como testemunha da irresistível corrupção no interior da comunidade inicial" (AC 44). Logo, a via pela qual os Evangelhos devem ser analisados precisa ser diferente daquela utilizada pela história no que concerne aos estudos de documentos ordinários. É mister, nesse caso, uma metodologia específica, adequada ao objeto que se tem em vista. Neste diapasão, Nietzsche faz a seguinte advertência: “-Esses evangelhos não 
podem ser lidos com suficiente cautela; por trás de cada palavra existem dificuldades" (AC 44). Na Vida de Jesus, Renan também toma o cuidado de indicar e averiguar as especificidades dos documentos evangélicos. A metodologia por ele utilizada tem muitas semelhanças com a de Nietzsche. Como se pode notar, para Nietzsche, o erro de Renan não está tanto em seu procedimento metodológico e sim na sua falta de tato em questões psicológicas, pois os Evangelhos exigem necessariamente essa atitude de seu leitor, pois afinal, as dificuldades "por trás de cada palavra" não são meramente acidentais, mas revelam igualmente a astúcia que subsiste nas deformações ali efetuadas:

Confesso, e espero que isto me seja perdoado, que justamente por isso eles [os Evangelhos] constituem, para um psicólogo, um prazer de primeira ordem - como o oposto de toda corrupção ingênua, como o refinamento par excellence, como talento artístico na corrupção psicológica. (AC 44).

De todo modo, a metodologia empregada por Renan se distancia dos procedimentos científicos habituais que a história costumava recorrer em sua época. De acordo com ele, para que a imagem histórica de Jesus possa vir a ser explicada é necessário lançar mão de hipóteses e conjecturas. Na busca de um quadro mais coerente e provável da vida de Jesus, é imprescindível apelar para a intuição e para a adivinhação. Ademais, um retrato mais coeso dos episódios que contam o nascimento do cristianismo exige até mesmo um alto grau de criatividade. Percebe-se, assim, que, em seu método histórico, Renan tenta salvar a história da condenação aristotélica de que a mesma consistiria num conhecimento cujo valor gnosiológico seria menor do que o da poesia. Como afirmava o Estagirita na Poética: "“[...] a poesia é algo de mais filosófico e mais sério do que a história, pois refere aquela principalmente o universal, e esta o particular" (ARISTÓTELES, Poética, IX, 1451b). Ou seja, por encerrar um rol de possibilidades superiores aos estudos históricos, a poesia consegue se aproximar mais de um conhecimento que abarque a essência dos acontecimentos.

Mas, por outro lado, tentando fazer da história uma espécie de "ciência artística", Renan acaba por se aproximar do que Aristóteles afirma ser a natureza da poesia. Como se constata em uma passagem do prefácio à $13^{\mathrm{a}}$. edição da Vida de Jesus:

2 ARISTÓTELES. Poética. Tradução de Eudoro de Souza. São Paulo: Nova Cultural, 1987. 
Qualquer circunstância verdadeira ou provável deveria então ter o seu lugar em minha narração, com sua nuança de probabilidade. Numa tal história, seria preciso dizer não somente o que aconteceu, mas ainda $o$ que poderia ter acontecido com verossimilhança. (RENAN, 2003a, p. 35, grifo nosso; 1995b, p. 18).

Vê-se, por conseguinte, que Renan pretende construir uma narrativa que se detenha na busca não da verdade, da certeza, do indubitável, do que deveras aconteceu, mas, sim, do que segundo as regras do entendimento é verossímil, possível e provável, o que poderia ter acontecido. Mas, dessa forma, o que Renan propõe é que o historiador se encarregue doravante do ofício próprio ao poeta como defende Aristóteles, pois: “[...] não é ofício do poeta narrar o que aconteceu [mas, sim, tradicionalmente, da história]; é, sim, o de representar o que poderia acontecer, quer dizer: o que é possível segundo a verossimilhança e a necessidade" (ARISTÓTELES, Poética, IX, 1541 a 36). Assim sendo, Renan afirma, ainda acompanhando o parecer aristotélico, ter visado pintar um quadro sobre a vida de Jesus no qual o todo transparecesse verossimilhança e necessidade, suas conjecturas visaram, segundo ele, oferecer uma imagem possível das origens do cristianismo, que exibisse uma harmonia entre luz e sombras (RENAN, 2003a, p. 83-84). Com isso, é possível dizer que o método de Renan encontra muitos pontos em comum com aquele que será adotado por Nietzsche, sobretudo no que diz respeito à solicitação da intuição e da adivinhação para compor um conjunto que esteja de acordo com a verossimilhança. ${ }^{3}$ É, portanto, tendo em vista essas precauções metodológicas que, de algum modo, aproximam Nietzsche de Renan, que mostraremos, em suas linhas gerais, a caracterização feita por Renan da figura de Jesus como herói e gênio.

\section{III}

Jesus representa, para Renan, um dos grandes homens que transformaram a fisionomia do mundo na busca da concretização de um grande ideal. Suas aspirações mostraram-se tão superiores à baixeza da consciência

\footnotetext{
Sobre a questão da "intuição" em Nietzsche, GIACOIA Jr, O. Labirintos da alma: Nietzsche e a auto-supressão da moral. Campinas: Editora da Unicamp, 1997. p. 71. Segundo Giacoia, “A reconstituição por Nietzsche para a figura histórica do Redentor, isto é, a reconstrução do tipo psicológico do Redentor, funda-se, sobretudo, num conhecimento intuitivo, em intuições congeniais (Einfühlung)."
} 
comum, que ele se viu obrigado a empreender uma luta contra a ordem das coisas, contra aqueles que sobrevivem à custa da mediocridade e da ignorância dos simples de espírito. Dessa forma, o conceito de herói funcionará para explicar tanto o caráter próprio de Jesus, quanto para mostrar o papel que sua vida representou para a humanidade. Sendo assim, Renan mostra, primeiramente, que por meio de suas intuições originais, Jesus levará a humanidade a um novo estágio de conhecimento espiritual, ao estabelecimento de um culto puro, de amor absoluto, de fraternidade universal. Sua jornada se liga aos portentosos feitos dos extraordinários heróis do passado, cujos sacrifícios garantiram à humanidade os seus mais preciosos avanços. A história de Jesus é, pois, uma tragédia na qual o arquétipo do herói mitológico é destroçado como promessa de uma nova vida. Nesse sentido, ele é, então, fundamentalmente, o herói da paixão, aquele que aceita livremente à morte em nome dos seus sonhos de amor à humanidade. Por outro lado, Jesus também é aquele que buscou inverter a ordem das coisas, que pôs os pobres, as mulheres e as crianças acima dos poderosos da terra. O homem que ousou desafiar os sacerdotes judaicos, revogando seus direitos exclusivos ao acesso das coisas divinas e dos poderes celestes. Nesse aspecto, Jesus é, pois, o herói revolucionário que aboliu a Lei e mostrou aos homens que todos os seus pecados estavam perdoados. Além disso, mostrou também que Deus era o Pai da bondade e da misericórdia suprema. Entretanto, além da concepção do herói revolucionário, a que chamou atenção da maioria dos intérpretes, ${ }^{4}$ é possível pensar que Renan também pensa numa outra concepção de herói, a de um herói trágico.

Afastando-se das concepções historicistas da época, Renan pretende tornar o seu relato histórico da vida e da obra do redentor uma espécie de drama trágico, um retrato artístico, em que cada parte mantivesse consonância com o todo, em que cada aspecto da narrativa fizesse parte de uma unidade ordenada e organizada. Viu-se que esse plano encontra-se apoiado nas concepções elaboradas por Aristóteles na Poética. Com isso, pode-se afirmar que ao buscar construir um relato no qual houvesse um equilíbrio entre todas as partes por meio daquilo que segundo as regras da lógica fosse verossímil, possível e provável, Renan sentiu necessidade de ressaltar seu personagem principal de forma a torná-lo interessante aos seus "leitores-espectadores": "Era preciso fazer meu herói belo e encantador

4 Para nos limitarmos à recepção brasileira, vale ressaltar que Fernando Barros enfatiza a dimensão revolucionária da figura do herói em Renan. BARROS, Fernando. A maldição transvalorada: o problema da civilização em O Anticristo de Nietzsche. São Paulo: Discurso Editorial; Ijuí: Editora da UNIJUÍ, 2002. p. 61. 
(pois, sem controvérsia, ele o foi); e isso, apesar dos atos que, em nossos dias, seriam qualificados de maneira desfavorável" (RENAN, 2003a, p. 35; 1995b, p. 19). Por conseguinte, é bem possível que Renan tivesse em mente, procurando agir como um bom poeta trágico numa visão aristotélica, compor seu herói de maneira a mostrar que de acordo com seu caráter e suas ações "uma após outra sucedidas, conformemente à verossimilhança e à necessidade, se dê o transe da infelicidade à felicidade ou da felicidade à infelicidade" (ARISTÓTELES, Poética, VII, 1451 a 6) de modo a apresentar, assim, a vida de Jesus sob a forma de uma beleza trágica tal qual nos fala Aristóteles. Afinal, como já foi apontado, é visando uma apreciação não só epistêmica, mas também estética de seus estudos históricos sobre a vida de Jesus que Renan procura oferecer um enredo coeso e organizado sobre as desventuras de tal personagem, buscando apresentar, para isso, "um relato vivo, humano, possível" (RENAN, 2003b, p. 35; 1995, p. 19), porquanto, como nos diz Aristóteles, "o belo consiste na grandeza e na ordem" (ARISTÓTELES, Poética, VII, 1450b 34, p. 207). É devido a esse paralelo que Renan procura ensejar entre os seus estudos históricos sobre a vida de Jesus e a concepção estética da Poética de Aristóteles, que ele buscará, sob determinado aspecto, pintar o redentor como um herói. Ora, sabe-se que, para Aristóteles, a tragédia tem uma função catártica, que a trama dos fatos que narram o destino do herói trágico tem como fim provocar o horror e a piedade, o que proporcionaria a liberação dessas emoções cujo acúmulo é nocivo (ARISTÓTELES, Poética, VI, 1449b 24). Talvez não seja o caso de se afirmar, contudo, que o objetivo da obra de Renan seja procurar igualmente um tal efeito trágico, mas que, ainda assim, Jesus, o herói da paixão, aquele que foi dilacerado para que uma vida abundante de amor, de boa vontade e de paz de espírito pudesse surgir, mereça ser tomado como um herói trágico, quiçá seja o que o autor tenta, de certa forma, sugerir. ${ }^{5}$

O conceito gênio, por sua vez, é utilizado por Renan para mostrar o significado extraordinário do ideal que Jesus procurou e, para o historiador francês, sob vários aspectos, conseguiu concretizar ao longo de sua jornada: "O mundo real não acabou, como Jesus havia anunciado, como seus discípulos acreditavam. Mas ele foi remodelado, e num sentido renovado como Jesus o queria" (RENAN, 2003, p. 287; 1995, p. 182). Dessa forma, o caráter elevado da obra de Jesus não pode ser atribuído, segundo Renan, a um simples sonho obsessivo de uma alma vulgar, a uma fantasia trivial de alguém perdido em vãs

\footnotetext{
É importante assinalar que Renan também chama o apóstolo Paulo, em algumas ocasiões de "herói”. No Capítulo 7 do Saint-Paul, por exemplo, ele diz que Paulo é o herói de Lucas na sua narrativa dos "Atos dos Apóstolos".
} 
divagações. Muito pelo contrário, Renan enxerga em Jesus um gênio cujas inspirações originais levaram o conhecimento e a experiência humana em coisas religiosas a um novo e praticamente insuperável patamar.

Contra uma posição bastante comum, Renan elucida que o modelo de educação do oriente não autoriza que se considere que Jesus foi um ignorante a despeito de não ter frequentado as escolas mais nobres dos escribas. A formação de Jesus deu-se mediante o contato com as escrituras nas sinagogas e nas suas demais convivências sociais. Ademais Jesus respirou como ninguém mais em sua época a atmosfera daquilo que se ensinava e se acreditava na Palestina naquele momento em que os preceitos de amor e caridade, tão caros a ele, já haviam sido disseminados pelo também pregador Hillel entre outros.

Não obstante, Renan revela que, sob certos traços, Jesus era bastante ingênuo. A configuração do mundo fora da Galileia, por exemplo, era-lhe totalmente desconhecida, quando não, sua visão sobre isso era de natureza completamente caricata, como indica Renan: "Que ele não tenha tido conhecimento algum do estado geral do mundo é o que revela cada traço de seus mais autênticos discursos. A terra ainda the parece dividida em reinos que guerreiam; parece ignorar a 'pax romana' e o novo estado da sociedade que seu século inaugurava" (RENAN, 2003, p. 112; 1995, p. 74). Sua noção de como as sociedades eram, de modo geral, econômica e politicamente constituídas, foi-lhe a mais imprecisa possível. Ele não tinha uma ideia clara do que significava a ambição dos homens por riqueza e poder. Por conseguinte, a genialidade de Jesus não é de modo algum aquela que o vulgo concebe como a de um homem capaz de resolver todos os problemas de qualquer área do saber humano. O conhecimento de Jesus, ou melhor, suas sublimes intuições, restringiam-se, segundo Renan, ao que diz respeito à espiritualidade, às aspirações religiosas da espécie humana, ao seu anseio por uma realidade superior, transcendente. E, nessa área específica da experiência humana, Jesus foi, para o historiador francês, o indivíduo mais original que já existiu, aquele que conseguiu elevar a noção judaica de Deus, em si, acredita Renan, já bastante superior às até então concebidas, a um grau de perfeição inatingível, porquanto, justifica Renan: "O Deus de Jesus não é o déspota injusto que escolheu Israel para seu povo e o protege de todos e contra todos. Éo Deus da humanidade [...] Elevando-se habilmente acima dos preconceitos de sua nação, ele estabelecerá a universal paternidade de Deus" (RENAN, 2003a, p. 139; 1995a, p. 91). É preciso, portanto, assevera Renan, apartar Jesus da normalidade dos membros de sua espécie.

Ora, aqueles que tentam fazer de Jesus um mero taumaturgo cujo carisma e arte no convencimento iludiu os seus seguidores a ponto de estes o elevarem a um status divino, agem, de acordo com Renan, por má-fé ou 
desnecessária petulância ante uma religião que perdurou por milênios nos corações humanos: "Um simples feiticeiro não teria encaminhado uma revolução moral como a que Jesus fez" (RENAN, 2003, p. 277; 1995b, p. 175). A obra de Jesus foi um feito inédito e insuperável: "[...] a religião de Jesus é, sob certos pontos de vista, a religião definitiva" (RENAN, 2003a, p. 403; 1995b, p. 255). Ao lado de outros grandes mestres e guias da humanidade, Jesus não só demarcou a história de uma área específica das práticas humanas, a saber, a religião, em antes e depois dele, como também fez o mesmo com a história de toda a civilização ocidental, e não por mero acidente dado à importância da experiência religiosa para a vida humana. E, afinal, "ele fixou para sempre a maneira como deve ser concebido o culto puro" (RENAN, 2003a, p. 404; 1995b, p. 256). Assim, Jesus uniu o homem a Deus por um elo inquebrantável, qual seja, a vida entregue ao amor. "Desse modo, 'cristianismo' tornou-se quase sinônimo de 'religião' [...] Jesus fundou a religião na humanidade, como Sócrates nela fundou a filosofia, como nela Aristóteles fundou a ciência" (RENAN, 2003a, p. 403; 1995b, p. 256). Portanto, conclui Renan, no que se refere às coisas religiosas, a despeito dos avanços que ainda podem ser realizados: "O Sermão da Montanha não será ultrapassado".

Renan admite que a sociedade ocidental hodierna seja incapaz de produzir esses casos formidáveis, porque o homem atual se vê tolhido pelas condições que a civilização lhe impõe para que o mesmo seja por ela acolhido. Em um mundo como esse, Jesus seria banido como um louco inconsequente, não seria sequer ouvido e sua obra morreria antes mesmo de haver nascido. Mas, num tempo e num lugar em que a individualidade não é sufocada, em que os homens são livres para fazerem de si mesmos algo original, casos como Jesus não são de modo algum inesperados. São épocas como essas em que os gênios precisam se tornar heróis (RENAN, 2003a, p. 405).

O ideal de Jesus não foi, pois, concebido por um deus, nem é também uma conquista coletiva fixada na forma de um mito, foi obra de um homem. Por isso, diz Renan: "Alcemos, então, no mais alto pico da grandeza humana, a pessoa de Jesus" (RENAN, 2003a, p. 405-406). Renan tem consciência de que muitos atribuem aos seguidores de Jesus a criação da imagem de um ser perfeito. Por isso, o historiador assevera que a despeito dos traços literalmente divinos na representação de Jesus, como por exemplo, a ausência de faltas e seu caráter impecável, os seus seguidores, longe de o retratarem como um ser sublime foram os responsáveis por o terem desfigurado e depreciado a natureza essencial e original de sua obra. Por isso, pior do que tentar ler Jesus nos Evangelhos é querer lê-lo através dos escritos paulinos e joaninos, ou dos Atos dos Apóstolos de influência paulina. Nesses escritos, 
torna-se patente à distância entre Jesus e aqueles que pretenderam continuar sua obra. A genialidade de Jesus se ausenta inteiramente no espírito daqueles que se diziam "divinamente inspirados" na tentativa de seguir seus passos.

Apesar de Jesus ser, para Renan, o único e legítimo fundador do culto puro, da verdadeira religião, é evidente que suas inspirações não surgiram do nada, para tanto, toda a humanidade, de certa forma, colaborou. Assim como vários progressos humanos foram alcançados, por diferentes vias, quase que simultaneamente em toda a terra, por homens que nunca tinham ouvido falar uns dos outros ou dos seus avanços particulares, o mesmo se deu no caso de Jesus: sua originalidade está em ter intuído espontaneamente os maiores avanços espirituais alcançados até então e os ter levado a um novo nível. Renan acredita que o espírito de Jesus foi um oceano para onde escoaram, por vias desconhecidas, as ideias mais importantes alcançadas ao redor do mundo por sábios inspirados, e nele, elas se fortaleceram até adquirirem uma densidade única (RENAN, 2003a, p. 408-409). Jesus foi, então, um gênio inspirado pelas aspirações religiosas mais sublimes já alcançadas. Ademais, seu surgimento foi fruto de um lugar e de uma época em que isso era possível e inevitável, assim como foi o surgimento dos grandes filósofos da antiguidade grega e dos brilhantes artistas do Renascimento.

Pode-se dizer que um dos motivos que levou Nietzsche a se confrontar diretamente com Renan na sua investigação do tipo psicológico de Jesus reside no fato de que o historiador francês já havia enunciado o desejo de realizar essa mesma tarefa. Quando jovem, em 1845, Renan, sofrendo gravemente com crises de consciência quanto a sua convicção na fé cristã, redigiu o ensaio Examen psychologique de Jésus-Christ, no qual afirmava: "Pretendo analisar Jesus Cristo como um fato psicológico e histórico, apreciá-lo, explicá-lo caso ele seja explicável, e, caso ele não o seja, cair de joelhos e atirar-me inteiramente nos braços de Deus" (RETAT, 1995). ${ }^{6}$ Portanto, a aproximação entre a perspectiva metodológica utilizada por Renan na Vida De Jesus e aquela adotada por Nietzsche em $O$ Anticristo, não é insólita, pois a aspiração do historiador francês sempre foi fazer uma reconstituição histórica de Jesus apoiada em observações psicológicas. É evidente que a psicologia a que se refere Renan não é idêntica àquela usada por Nietzsche, mesmo porque o filósofo alemão se considera o inventor da psicologia. ${ }^{7}$ Ora, ainda no mesmo texto de 1845, Renan expressa seu problema da seguinte forma: "Eis aqui a expressão mais simples de meu problema. Explicar se é possível, pelas leis psicológicas, a aparição de Jesus Cristo ou de relacioná-la com o tempo

6 RÉTAT, Laudyce. "Introduction”. In: RENAN, 1995.

7 EH Por que sou um destino 6. A respeito da psicologia em Nietzsche, WOTLING, 1999; GIACOIA JR., 2001. 
e o lugar em que ele apareceu." Ou seja, Renan deseja apreender Jesus a partir do ambiente em que o mesmo viveu. Descobrir como, de acordo com as convenções psicológicas, o espírito do redentor se formou a partir do contato com um lugar e com uma época determinada, mostrando como juízos preconcebidos em um período mais recente podem acabar por desfigurar o seu caráter. Esse é o procedimento que o historiador exibe diversas vezes ao longo de sua explicação das origens do cristianismo em Vida de Jesus (RENAN, 2003a, p. 29). Na perspectiva de Renan, o lugar, o momento, os acontecimentos, em suma, a atmosfera na qual a alma de Jesus estava inserida assume, na obra Vida de Jesus, uma importância decisiva para a reconstituição de seu caráter.

Para Nietzsche, ao contrário, o que interessa é tão somente o tipo psicológico de Jesus e como esse estado fisiológico determinado estabelece suas relações com o ambiente externo. O que pesa nas apreciações de Nietzsche é, então, muito mais a constituição interna de Jesus e não tanto o meio no qual ele viveu. Dessa forma, a reconstituição histórica da alma de Jesus, é o primeiro deslize cometido por Renan em psicologia. Como aponta Nietzsche: "As tentativas que conheço de extrair dos evangelhos até a história de uma alma [referência a Renan] me parecem prova de uma execrável leviandade psicológica" (AC 29). O segundo e mais grave erro de Renan no terreno psicológico, foi ter mobilizado os conceitos de herói e gênio para esclarecer quem foi Jesus e qual o caráter de sua obra. Em virtude disso, Nietzsche denuncia: "O senhor Renan, esse bufão in psychologicis [em coisas psicológicas], utilizou em sua explicação do tipo Jesus os dois conceitos mais inadequados que pode haver nesse caso: o de gênio e o de herói ("héros')" (AC 29). ${ }^{8}$

O tipo psicológico de Jesus diagnosticado por Nietzsche éo do "idiota", concepção que encontra suas raízes, como sabemos, em Dostoiewski. Tal tipo, por sua vez, não poderia se compatibilizar com a noção de herói, isto é, alguém que, como Renan afirma, decide lutar para que o seu ideal se torne realidade, alguém que combate, alguém que não aceita, que nega as coisas tais como são e resolve mudá-las. Nada disso, na interpretação de Nietzsche, pode adequar-se ao caráter próprio de Jesus e à realidade evangélica vivenciada pelo seu tipo: "Se existe algo não evangélico, é o conceito de herói. Justamente o contrário de todo pelejar, de todo sentir-se-em-luta, tornou-se aí instinto [...]" (AC 29). A não-resistência é uma condição de existência para o tipo idiota, uma condição fisiológica que se transmutou em moral. Como conceber, pois, um ser cujo instinto é nunca se opor, em pleno combate com a casta sacerdotal dos judeus e contra todos os poderosos do mundo como o quer Renan? "Fazer de Jesus um herói!" (AC 29), exclama Nietzsche. Ora,

8 A respeito da superação do "heroísmo" nos últimos textos de Nietzsche, ver CAMPIONI, In: MARTON, 2007. 
pelo contrário, o filósofo observa: "Em seus instintos mais profundos, Jesus é nãoheróico [unheroisch]: não luta jamais: quem vê nele algo como um herói, como faz Renan, vulgarizou o tipo até torná-lo irreconhecível" (KSA 13, p. 237).

Nietzsche admite, entretanto, que a prática de Jesus agredia necessariamente a Lei judaica, pois denunciava toda a sua crueza, incoerência e prejuízo. Porém, Jesus não atacou deliberadamente a Igreja judaica, ele não poderia, não tinha constituição alguma para isso. Como explica Fernando Barros em seu livro A maldição transvalorada: "[...] a prática de Jesus possibilitou um tal desnudamento da lei judaica, todavia faltava-lhe o ânimo belicoso para investir efetivamente contra a ordem moral do mundo" (BARROS, 2002, p. 66). Jesus não tinha, portanto, de acordo com Nietzsche, real consciência das consequências advindas de sua prática. Por isso, o cristianismo foi um levante das camadas baixas do judaísmo contra o poder sacerdotal constituído, mas Jesus não tinha consciência alguma que uma tal insurreição ocorreria em nome de seu modo de viver. "-E que mal-entendido é sobretudo a palavra 'gênio'!" (AC 29), admira-se Nietzsche. Ora, o tipo idiota só conhece uma única realidade: suas vivências interiores. Todo o mundo exterior é, em sua efetividade, desconhecido para ele. Imaginar que Jesus tenha, mediante inspirações e intuições originais, contribuído para elevar o saber pavimentado por outros fundadores de religiões ao redor do mundo, é, para Nietzsche, um total absurdo. Como assevera o filósofo: "Todo o nosso conceito, nosso conceito cultural de 'espírito' não tem qualquer significado no mundo em que Jesus vive" (AC 9). ${ }^{9}$ Por conseguinte, toda a ideia de cultivo da individualidade por meio de aquisições de conhecimentos culturais, isto é, a noção de formação espiritual, não pertence à realidade na qual o tipo psicológico de Jesus habita. Tudo aquilo que um tal tipo concebe é deveras original, mas no sentido de único, exclusivo, próprio, que jamais pertenceu a qualquer um, que não é, pois, um bem cultural nem fruto de um cultivo da individualidade. A forma como o tipo de Jesus interpreta as coisas é proveniente de um voltar-se sobre si mesmo, de um extremo cuidado para com as suas vivências íntimas, para a sua interioridade. Assim sendo, o olhar de Jesus sobre o mundo não foi, segundo Nietzsche, adquirido por uma formação espiritual,

9 A tradução dessa passagem foi modificada. Na tradução de Paulo César de Souza lê-se: "Nada de nosso conceito de 'gênio', um conceito de nossa cultura, tem algum sentido no mundo em que vive Jesus" (AC, p. 36). No original alemão está: Unser ganzer Begriff, unser Cultur-Begriff 'Geist' hat in der Welt, in der Jesus lebt, gar keinen Sinn (KSA, Vol. 6, p. 200). Seguimos, pois, neste caso, as traduções francesa e espanhola: Toute notre conception de l' esprit', conception née de la culture, n'a aucune signification dans le monde où vit Jésus (AC, p. 42); Nada de nuestro concepto, de nuestro concepto cultural 'espíritu' tiene sentido alguno en el mundo en que Jesús vive (AC, p. 58). Nesse caso a tradução de Paulo César de Souza faz uma substituição problemática do termo "espírito" por "gênio". 
ou, como defendia Renan, intuído por ele ao respirar como ninguém a atmosfera do saber religioso de sua época; foi, sim, o resultado de sua percepção sobre qual seria a melhor maneira para ele, ou seja, para alguém com a sua constituição, relacionarse com o mundo com vista a poder experimentar a suprema beatitude.

\section{Referências}

ARISTÓTELES. Poética. Tradução de Eudoro de Souza. São Paulo: Nova Cultural, 1987.

BARROS, F. A maldição transvalorada: o problema da civilização em O Anticristo de Nietzsche. São Paulo: Discurso Editorial; Ijuí: Editora da UNIJUÍ, 2002.

CAMPIONI, G. Nietzsche: do agonismo extemporâneo à crítica da moral heróica. In: MARTON, Scarlett (Org.). Nietzsche pensador mediterrâneo: a recepção italiana. São Paulo: Discurso Editorial; Ijuí: Editora da UNIJUÍ, 2007.

Les lectures françaises de Nietzsche. Paris: PUF, 2001.

ETS, 1992.

Introduzione. In: RENAN, Ernest. Dialoghi filosofici. Pisa: Edizioni

DOSTOIÉVSKY, F. O Idiota: romance em quatro partes. Tradução, prefácio e notas de Paulo Bezerra. São Paulo: Editora 34, 2002.

GIACOIA Jr., O. Labirintos da alma: Nietzsche e a auto-supressão da moral. Campinas, SP: Editora da Unicamp, 1997.

. Nietzsche como psicólogo. São Leopoldo, RS: Editora da Unisinos, 2001.

NIETZSCHE, F. Sämtliche Werke: Kritische Studienausgabe (KSA). Hrsg. von Giorgio Colli und Mazino Montinari. Berlin/München/New York: Walter de Gruyter/DTV, 1986.

O Anticristo: maldição ao cristianismo/Ditirambos de Dionisio. Tradução, notas e posfácio de Paulo César de Souza. São Paulo: Companhia das Letras, 2007.

O caso Wagner: um problema para músicos./Nietzsche contra Wagner: dossiê de um psicólogo. Tradução, notas e posfácio de Paulo César de Souza. São Paulo: Companhia das Letras, 1999. 
Crepúsculo dos ídolos ou como se filosofa com o martelo. Tradução, notas e posfácio de Paulo César de Souza. São Paulo: Companhia das Letras, 2006.

Ecce homo: como alguém se torna o que é. Tradução, notas e posfácio de Paulo César de Souza. São Paulo: Companhia das Letras, 1995.

Além do bem e do mal. Tradução, notas e posfácio de Paulo César de Souza. São Paulo: Companhia das Letras, 1992.

L'Antéchrist: imprecation contre le christianisme. Traduit de l'allemand par Jean-Claude Hémery. Paris: Gallimard, 2004.

El Anticristo: maldición sobre el cristianismo. Traducción, introdución y notas Andrés Sánchez Pascual. Madrid: Alianza, 2003.

RENAN, E. Vie de Jésus. In: RENAN, E. Histoire des origines du christianisme. Paris: Robert Lafont, 1995a.

Saint-Paul. In: RENAN. E. Histoire des origines du christianisme. Paris: Robert-Lafont, 1995b.

Vida de Jesus. Tradução de Eliana Maria de A. Martins. São Paulo: Martin Claret, 2003a.

Paulo: o $13^{\circ}$ apóstolo. Tradução de Tomás de Fonseca. São Paulo: Martin Claret, 2003b.

RÉTAT, L. Introduction. In: RENAN, E. Histoire des origines du christianisme. Paris: Robert-Lafont, 1995.

WOTLING, P. La pensée du sous-sol. Paris: Allia, 1999.

Recebido: 14/06/2008

Received: 06/14/2008

Aprovado: $12 / 08 / 2008$

Approved: 08/12/2008 